\title{
NEW FORMS OF POLISH-SLOVAK TRANSFRONTIER COOPERATION
}

\author{
Łukasz Lewkowicz \\ Faculty of Political Science, Maria Curie-Skłodowska University in Lublin \\ Plac Litewski 3, 20-080 Lublin, lewkowicz83@gmail.com
}

\begin{abstract}
Summary. The aim of this article is to analyse new forms of territorial cooperation on the PolishSlovak borderland. Currently, this type of collaboration is mainly carried out by the Euroregions. Planned changes in the European Union's cohesion policy for the 2014-2020 period will determine the structural and functional transformations on these „traditional” entities. This article will present European Groupings of Territorial Cooperation (EGTC), which are currently being formed on the borderland, along with the concept of the Carpathian Euroregion - „Carpathian Horizon 2020". At the outset, the nature and normative basis of the new EU legal instrument, which is EGTC, will be explained. Two currently established Polish-Slovak groupings, as well as the idea of „Carpathian Horizon 2020" will be analysed. The founding documents, internal organization and planned scope of their activities will be described in detail.
\end{abstract}

Key words: European Groupings of Territorial Cooperation, Euroregions, transfrontier cooperation, Polish-Slovak borderland, „Carpathian Horizon 2020”

\section{INTRODUCTION}

Jean Monet tried to convince people to act together because, despite the boundaries existing between them, they have common interests. This idea inspired political and social activists who have been developing trans-frontier cooperation since the $1950 \mathrm{~s}$. Up to the beginning of the $21^{\text {st }}$ century, the most popular entities pursuing this kind of cooperation were the Euroregions. They originated in post-war Western Europe as a way to overcome prejudices and prevent conflicts between recent opponents as well as to provide solutions for borderlands' economic development. Dynamic changes in the international environment, including the current budget of the European Union for the 20142020 period, resulted in the need for a major transformation of institutional cooperation. At present, a great opportunity for Euroregions is created by a new, alternative EU legal institution - European Grouping of Territorial Cooperation (EGTC). The purpose of this article is to conduct a political analysis of currently forming new forms of trans-frontier cooperation on the Polish-Slovak borderline: Tatra EGTC, TRITIA EGTC and „Carpathian Horizon 2020”. The article 
will discuss their founding documents, internal organization, and intended scope of activity.

\section{THE CONCEPT AND ESSENCE OF THE EGTC}

European Grouping of Territorial Cooperation is an institution introduced within the Community Law which allows for the creation of formal groups of cooperation by public entities from different Member States. It is a response to the problems which resulted from different legal systems in different countries and which were earlier faced by the Euroregions. The establishment of an EGTC aims to avoid these difficulties and provide greater harmonization to jointly implemented territorial cooperation. In addition, through the use of this new legal instrument, a greater economic and social cohesion is possible in the longer term, referring to Article 159 of the Treaty establishing the European Community (EC) [Dołzbłasz and Raczyk 2010].

EGTC's legal basis is provided by European Regulation (EU) No. 1082/2006 of the European Parliament and of the Council of 5 July 2006 on a European Grouping of Territorial Cooperation (EGTC) ${ }^{1}$. Because the regulation has the force of law and is directly applicable, its article 16 obliges Member States to establish rules to ensure the effective application of the Community's regulation. For this purpose, appropriate acts on EGTCs were prepared in both Poland and Slovakia. When it comes to Poland, on December $9^{\text {th }}, 2008$, the Polish Parliament adopted the Law on the European Grouping of Territorial Cooperation, which entered into force on January $9^{\text {th }}, 2009$. The new law made it possible to apply the Regulation from 2006 in Poland, as well as allowing the establishment of groupings on its territory and participation in EGTCs of Polish entities established in other countries ${ }^{2}$. In the same year, a regulation on keeping a register of groupings was also adopted ${ }^{3}$. In the case of Slovakia, the question of the form and joining EGTCs was regulated by the Act of February $15^{\text {th }}, 2008$. With the introduction of efficient implementing solutions, Slovakia currently holds the largest number of newly established groupings in Central Europe to the present day, and many more are in the making ${ }^{4}$.

EGTC's tasks are mainly related to the implementation of EU-financed programs and projects of territorial cooperation. On the one hand, agrouping's activity may focus on one specific task, and on the other, it may implement mul-

\footnotetext{
${ }^{1}$ Dz. U. UE nr L 210/19 z 31.07.2006.

${ }^{2}$ Dz. U. 2008, nr 218, poz. 1390.

${ }^{3}$ Rozporzadzenie Ministra Spraw Zagranicznych z dnia 17 czerwca 2009 r. w sprawie sposobu prowadzenia Rejestru Europejskich Ugrupowań Wspólpracy Terytorialnej, Materials of the Ministry of Foreign Affairs in Warsaw.

${ }^{4}$ Zákon o európskom zoskupeni územnej spolupráce a o doplneni zákona č. 540/2001 Z. z. o štátnej štatistike $v$ zneni neskoršich predpisov - Zákon č. 90/2008 Zb.
} 
tiple tasks and projects. The entities, which constitute an EGTC, may only take those actions that fall within their competence set by national legislation. This makes it necessary to develop a specific „common denominator” of competences by individual actors. Areas traditionally reserved for the state, police powers, legislative, justice and foreign policy, are excluded from the scope of activities of an EGTC [Dumała 2009a].

A grouping can be established by entities in least two Member States and might include the states, themselves, regional and local authorities, public law entities and associations which include actors belonging to all of those categories. Groupings are required to have an Assembly, as a representative body, and a Director, who represents the grouping and acts on its behalf. At first, the members of the grouping are obliged to sign a convention, containing terms and conditions of their cooperation (name, location, geographical scope, membership, and objectives). Then, on the basis of this document, the statute defining, among other things, the authorities of the grouping and rules regarding the budget and financial responsibility is adopted. In the next stage, the members of the grouping inform the authorities of the competent member state where they are established, of the willingness to participate in the grouping, and present to it the convention and statute. The competent state authority grants permission or, in case of refusal, the reasons [Dołzbłasz and Raczyk 2010].

An EGTC is funded by institutions forming the grouping. The cost of its foundation and ongoing activities is covered from own funds, primarily from membership fees. Moreover, the grouping may apply for EU funds for the funding of various projects. The grouping is responsible for its obligations. However, insofar as the assets of an EGTC are insufficient to meet existing commitments, it is the members who bear financial responsibility. If the liability of one of its members is limited by national law, the remaining members may also limit their liability in the statutes. Then the name of the grouping is supplemented by the term „limited liability" [Bussmann 2008].

The feature distinguishing an EGTC from other institutions promoting territorial cooperation is its legal personality and, consequently, the full capacity to act within the meaning of different national legal systems. This means that an EGTC may acquire and dispose of movable and immovable property, hire employees, and be a party to legal proceedings. An EGTC shall acquire legal personality upon registration or publication of the statute in accordance with the national law of the Member State where the registered office of the new grouping is established [Bussmann 2008, Dumała 2009b]. 


\section{HISTORICAL EXPERIENCE OF TRANS-FRONTIER COOPERATION}

Polish-Slovak transfrontier cooperation has passed several important milestones in recent history. In the interwar period, the signing of the Prague Convention was a moment of great significance due to numerous, mainly ethnic, conflicts. The Convention dealt with questions of mutual cooperation and enabled economic, cultural and scientific development. In addition, under the Tourism Convention free travel in the Polish-Slovak border area was introduced. It was reintroduced in the $1950 \mathrm{~s}$, due to positive changes after World War II. Rules on local border traffic were mitigated, which benefited mainly the local population. The 1980 s provided a time of isolation and a significant reduction in mutual relations. A turning point in the relationship occurred only in the 1990s when, with the transformation and reactivation of local governance, crossborder cooperation in its modern form started to develop [Dołzbłasz and Raczyk 2010]. A key role in this process was played by the EU supported Euroregions. The first one created in this considered border area was the Carpathian Euroregion, which was brought to life on February $14^{\text {th }}, 1993$ in Debrecen, Hungary. It is territorially one of the largest Euroregions in Europe. It covers border regions of Poland, Slovakia, Ukraine, Hungary and Romania. Creation of the Euroregion was a top-down process - it was established by the governments of those countries, and its formation was accompanied by various controversies, such as a heated debate in the Polish parliament, or Vladimir Meciar's government opposition in Slovakia). Another Euroregion - Tatra - was inaugurated on August 26th, 1994, in Nowy Targ, Poland, as a grassroots initiative of PolishSlovak local authorities in the Tatra and Sub-Tatra Mountains area. Euroregionalisation of the Polish-Slovak borderland ended with the creation of Beskids Euroregion on February $18^{\text {th }}, 2000$ in Rajcza, Poland. It supports Polish-CzechSlovak cooperation in the region of the Beskids Mountains and Podbeskidzie [Lewkowicz 2012].

\section{EGTC ON THE POLISH-SLOVAK BORDERLAND}

Currently, the most advanced effort to transform into EGTC is taken by Tatra Euroregion. The first step forward for the transformation of the Euroregion into an EGTC was the resolution of the $13^{\text {th }}$ Congress of the Tatra Euroregion, which took place on 16 March 2007. It obliged the Council to appoint a special working group that would monitor the legislative process for introducing the EGTC regulation into Poland and Slovakia and prepare appropriate documentation in this regard. New Commission on the EGTC was created on May $9^{\text {th }}, 2007$. Its work resulted in development of framework draft conventions and statutes for the EGTCs. These were presented to the $15^{\text {th }}$ Congress of the Tatra 
Euroregion on April 17, 2009. Simultaneously, the Polish-Slovak Declaration on the establishment of a European Grouping of Territorial Cooperation was approved. This act constitutes the first formal step towards the establishment of a new grouping 5 .

A major problem the Tatra Euroregion struggled with in the first stage of the transformation was the limited financial resources to achieve the goal. The work on the establishment of the EGTC on Sub-Tatra region gathered momentum with the adoption of the common Cross-Border Cooperation Programme Poland-Slovak Republic 2007-2013. The Euroregion's authorities then considered the question of the establishment of the EGTC to be one of their top priorities and, therefore, in March 2010 the Congress recommended the implementation of the strategic project „From the Tatra Euroregion to the European Grouping of Territorial Cooperation". After evaluation of the application by the Monitoring Committee, the project was approved for funding in December $2010^{6}$. This project was intended to help in financing the construction of relatively expensive new EGTC structures and thus, contribute to the finalization of institutional and legal transformation processes initiated in $2007^{7}$. The lead partners of the project are Polish and Slovak parties, especially the cities of Nowy Targ, Poland, and Kezmarok, Slovakia. The main objective of the project is to improve Polish-Slovak trans-frontier cooperation to a higher organizational and legal level. The main beneficiaries of the initiative will include the local government units that form the Tatra Euroregion, and the local border community ${ }^{8}$.

Currently, the Tatra Euroregion is developing key documents for the new grouping. At the March 2011 Congress of the Tatra Euroregion Union in Lapsze Niżne, Poland, a draft convention on setting up the Tatra European Grouping of Territorial Cooperation was adopted. During the meeting, the members of the Commission on the EGTC were obliged to conduct further work on the convention and the statute, and to present their final versions for approval by the Extraordinary Congress of the Tatra Euroregion. In addition, the Council and the Director of the Tatra Euroregion Office in Nowy Targ were authorized by the Congress to request permission from the Board and the Assembly of Małopolskie Voivodeship to support efforts on the establishment of the new EGTC, as

5 Uchwała Nr 3 XV Kongresu Transgranicznego Zwiazku Euroregion „Tatry” z dnia 17.04.2009 r. w sprawie: Deklaracji dotyczacej utworzenia Europejskiego Ugrupowania Wspótpracy Terytorialnej, Materials of Tatra Euroregion Office in Nowy Targ, Poland.

${ }^{6}$ Posiedzenie Komitetu Monitorujacego 14-15 grudnia 2010 - lista projektów zatwierdzonych do dofinansowania, http://pl.plsk.eu/news/? lang_id=3\&id_news $=644, \quad$ p. $6, \quad[$ access on 15.02.2013].

${ }^{7}$ Uchwała Nr 2 XVI Kongresu Transgranicznego Zwiąku Euroregion „Tatry” z dnia 24.03.2010 r. w sprawie: projektów strategicznych Transgranicznego Związu Euroregion „Tatry", Materials of Tatra Euroregion Office in Nowy Targ, Poland.

${ }^{8}$ Od Euroregionu „Tatry” do Europejskiego Ugrupowania Wspótpracy Terytorialnej, Materials of Tatra Euroregion Office in Nowy Targ, Poland, p. 2-4. 
well as to ask for financial support for the Euroregion's own contribution to this project ${ }^{9}$.

According to the draft convention, the official name of the new grouping will be the Tatra European Grouping of Territorial Cooperation. The EGTC will be formed by national parties of the Tatra Euroregion, as well as the cities of Nowy Targ, Poland, and Kezmarok, Slovakia. The agreement provides the following internal structure: the General Assembly, the Board, the Audit Committee and the Directorate for European Funds. The main objective of the grouping is to facilitate further development of Polish-Slovak transfrontier cooperation in the economic, social and environmental fields, according to the principles of partnership and equality of the parties. These tasks will be possible thanks to the programs and projects of cross-border cooperation co-financed by the $\mathrm{EU}^{10}$. It should be noted that only on November $8^{\text {th }}, 2011$ did the Commission for the EGTC finally opt for a selection of multi-purpose groups, focusing on the implementation of the Broad's objectives ${ }^{11}$.

Another interesting initiative to be considered in this borderland is TRITIA EGTC, which was initiated by the local authorities - on the Polish side, of Silesia and Opole Voivodeships, while on the Czech and Slovak sides, respectively, by the Moravian-Silesian and Žilina Regions ${ }^{12}$. This project deserves special attention because all existing Euroregions in the area, including the Beskids Euroregion, were also invited to develop this cooperation ${ }^{13}$. For the first time the idea of creating a new grouping was presented at a meeting of representatives of the mentioned regions in June 2009 in Katowice, Poland. The result of the common understandings was the introduction of a working group composed of experts from different regions, which within six months would have developed a basic framework documents (convention and statute) associated with the establishment of the new EGTC. Subsequently, on January $29^{\text {th }}, 2010$, a meeting of leaders of four regions was held in Žilina, Slovakia, during which they came to an agreement on all issues related to the creation and further activities of the

\footnotetext{
${ }^{9}$ Uchwała Nr 2 XVII Kongresu Zwiazku Euroregion ,Tatry” z dnia 02.03.2011 r.w sprawie: Europejskiego Ugrupowania Wspótpracy Terytorialnej, Materials of Tatra Euroregion Office in Nowy Targ, Poland.

${ }^{10}$ Konwencja o powołaniu Europejskiego Ugrupowania Wspótpracy Terytorialnej „,Tatry” (draft), Materials of Tatra Euroregion Office in Nowy Targ, Poland, p. 1-4.

${ }^{11}$ Posiedzenie polsko-stowackiej Komisji ds. Europejskiego Ugrupowania Wspótpracy Terytorialnej, http:// www.euroregion-tatry.eu/posiedzenie_polskoslowackiej_komisji_ds_europejskiego_ugrupowania_wspolpracy_terytorialnej,132,n.html, [access on 20.02.2013].

${ }^{12}$ Vzniká prvé stredoeurópske združenie územnej splupráce, http://zilina.sme.sk/c/5215821/vznika-prvestredoeuropske-zdruzenie-uzemnej-spoluprace.html, [access on 25.02.2013].

${ }^{13}$ Przyszlość wspótpracy terytorialnej nie taka straszna, http://www.silesia-europa.pl/index.Php jezyk=pl\&grupa=10\&art. $=1289378610 \&$ id_menu=1, [access on 25.02.2013].
} 
grouping ${ }^{14}$. To date, the parties have succeeded in negotiating provisions of the convention and the statute of the new EGTC. Both documents were initially accepted by the founding authorities of the four regions involved in the grouping. In February 2012 it was approved by the Silesian Regional Assembly. The local assembly also authorized the Marshal of Silesian Voivodeship to sign the conventions and register the grouping ${ }^{15}$.

Under the convention, TRITIA EGTC's headquarters is set in the city of Cieszyn, Poland. For this reason, the organization will be guided in its activities by Polish law, and any disputes between the parties will be resolved by settlement or by the Polish courts. The new grouping aims to facilitate and promote trans-frontier cooperation between local authorities of Poland, the Czech Republic, and Slovakia. It shall be done mainly by managing EU projects and programs for strengthening economic and social cohesion in the region and in such fields as transport and infrastructure, economy, tourism and energy. It also includes cooperation in the areas of culture, environment, human capital development, sports and between public institutions. The EGTC is to be financed mainly by membership fees and contributions from the EU. However, the grouping's income will also consist of public funds, donations, legacies and profits from its own businesses. The amount of the first membership fee was set at 22000 Euros $^{16}$.

TRITIA's statute regulates in detail the issue of the internal organization of the new grouping. Its bodies are: the General Assembly, the Director and the Supervisory Board. The highest authority in the EGTC will be the General Meeting, which is a body consisting of four representatives - one from each party. Its mandate should be, among other things, to adopt action plans and a budget and to approve annual financial statements and operations, the selection and dismissal of the Director and the Supervisory Board, and the dissolution and liquidation of the grouping. Resolutions of the Assembly shall be taken unanimously. Grouping executive function will be performed by the Director, responsible for the external representation of the organization, the preparation and execution of resolutions of the General Assembly, and managing current operations. The Director will be supported by an auxiliary, the Secretariat of the EGTC located in Czech Cieszyn. However, control over the grouping's activities will be held by a four-person Supervisory Board. The powers of this body will include, among other things, supervision of the grouping's operations, selection of an auditor to examine the accounts of the EGTC, and submission of

\footnotetext{
${ }^{14}$ Konwencja o utworzeniu Europejskiego Ugrupowania Wspólpracy Terytorialnej „TRITIA” z ograniczonq odpowiedzialnościa, Materials of Marshal Office of Silesian Voivodeship in Katowice, Poland, p. 1.

15 Regiony z Polski, Czech $i$ Stowacji powotuja wspólna organizację, http://wyborcza.pl/1,91446,11137263, Regiony_z_Polski_Czech_i_Slowacji_powoluja_wspolna.html, [access on 25.02.2013].

${ }^{16}$ Konwencja o utworzeniu Europejskiego Ugrupowania Wspótpracy Terytorialnej „,TRITIA"..., p. 3-4.
} 
an opinion on the financial statements to the General Assembly ${ }^{17}$. The new EGTC will cover an area of $34000 \mathrm{~km}^{2}$ and have a population of about 8 million inhabitants ${ }^{18}$.

\section{„CARPATHIAN HORIZON 2020”}

Besides the above mentioned collective actions, special attention should be paid to an initiative by the Polish party of the Carpathian Euroregion in 2004 called „Carpathian Horizon 2020". It provides that a special operating programme on development of the Eastern Carpathians, within the financial perspective 2014-2020 should be prepared. The program, operatively called the Carpathian Space Programme, is to be modelled on existing multilateral operational programs aiming to support geographically homogeneous border areas in Western Europe. It is estimated that the planned Carpathian Programme will have a budget of around 150-500 million euros. The project will enable the funding for „soft" projects promoting cooperation of local communities in the Eastern Carpathians; institutional projects on the creation of professional institutions, organizations and networks working to support economic development of the area; as well as large investment projects in the fields of infrastructure, environment protection and tourism. As an institution, the Carpathian Euroregion will gain the capacity to manage the program autonomously ${ }^{19}$.

„Carpathian Horizon 2020" involves the upgrade of the internal structure of the Carpathian Euroregion and aims to achieve ambitious institutional goals. According to previous arrangements, the office of Carpathian Euroregion Association Poland in Rzeszów will provide the Secretariat for the new project. It is in constant cooperation with other Euroregion's offices in Sambor, Ukraine, and Kosice, Slovakia. Elections of new authorities, which include the Programme Council, the Steering Committee and the Coordinating Team, will be the first step towards the implementation of the „Carpathian Horizon 2020". Programme Council is to be a collegial body gathering politicians, experts, academics and journalists, whose mission is to promote the concept and support the project bodies with their authority and knowledge. It is proposed that each national party should delegated five representatives to the Council. The Steering Committee will perform the decision-making functions. Its core competencies will

\footnotetext{
${ }^{17}$ Statut Europejskiego Ugrupowania Wspólpracy Terytorialnej ,,TRITIA” z ograniczona odpowiedzialnościa, Materials of Marshal Office of Silesian Voivodeship in Katowice, Poland, p. 5-11.

${ }^{18}$ Information from the website of the EU Committee of the Regions: http://portal.cor.europa.eu/egtc/en-US/Projects/already/Pages/welcome.aspx, [access on 25.02.2013].

${ }^{19}$ Opis działalności Stowarzyszenia Euroregion Karpacki Polska, Materials of the Carpathian Euroregion Office in Rzeszów, p. 8-9; , Rozwój Karpat podczas Prezydencji Polski w Radzie Unii Europejskiej" - międzynarodowa konferencja w Przemyślu, http://rzeszow.uw.gov.pl/main.php? muid= $=3 \& \mathrm{mid}=17 \& \mathrm{AKID}=10776 \& \mathrm{cid}=4421582 \mathrm{ca} 2225 \mathrm{bd} 8$, [access on 01.03 .2013 ].
} 
include channelling the development of the program, making decisions related to its implementation, and responding to and tackling emergency situations. Members of the Committee are to work closely with the President and the Coordinating Team. As in the case of the Program Council, the Committee will consist of 5 people. However, the Coordinating Team will consist of experts responsible for project implementation ${ }^{20}$.

This concept proposes deeper institutional changes. First, it implies the creation of the International Centre for Interregional and Cross-Border Cooperation in Rzeszów, Poland. It is planned as a professional organization operating under the auspices of the Congress of Local and Regional Authorities of the Council of Europe, realizing tasks of coordination and promotion of transfrontier and interregional cooperation on the Eastern borderland of the EU. The Congress of Central, Southern and Eastern Europe Border Regions will support the Centre as well. The main task of this body will be to implement the Carpathian Programme in 2014-2020. There is a strong probability that Marshal Office of Podkarpackie Voivodeship will act as its managing authority. The final authority provided under this concept is the Joint Technical Secretariat for the Carpathian Programme in Rzeszów, which will be responsible to the managing authority for the administration of the Carpathian Programme, including by activities such as training, counselling, calling for proposals, the formal and technical evaluation of projects, and then contracting, monitoring, billing and reporting on those projects. In view of its experience with the implementation of EU funds, the Carpathian Euroregion Association Poland will assume the function of the Joint Secretariat ${ }^{21}$.

\section{CONCLUSION}

The creation of EGTCs is a further step towards the standardization and harmonization of transfrontier cooperation in the EU. Progressive formalization of cross-border cooperation, however, can have both positive and negative results. Undoubtedly, the positive effect of the creation of EGTCs on the Polish-Slovak borderland may be the strengthening of an institutional structure of cooperation, and thus, increasing the powers of institutions dealing with transfrontier collaboration. Formalization of this cross-border cooperation will enable a stronger inclusion of this kind of cooperation as an instrument of foreign policy for both countries. Transferring the role of managing authorities of crossborder operational programs in the new EU budget to EGTCs can be a great opportunity for them. This will foster the implementation of large and costly infrastructure investments. This will also allow for the expansion of existing

\footnotetext{
${ }^{20}$ Opis działalności..., p. 10

${ }^{21}$ Ibidem, p. 11.
} 
road and rail connections and the construction of missing ones. The existence of an institution with legal personality will allow for greater accountability of partners to contracts and agreements in financial matters, too. A greater number of trans-frontier entities committed to cooperation has the potential to be a positive aspect of the creation of EGTCs as well. Moreover, additional funding will promote the EU's borderland to the outside to a greater extent. And finally, they will also allow for the conduct of more advanced and specialized studies on the borderland.

Still, some questions remain: how efficient will the currently created Polish-Slovak EGTCs be? Will other Euroregions operating on this border formally convert to EGTCs? What will be the interest of the local government units in this optional instrument of cooperation? And finally, will the territorial units recognize EGTCs as a more convenient, beneficial and easier legal tool to use than previously used tools? At this point it is extremely difficult to give clear answers. It is highly likely that EGTCs will occur both next to and on the basis of existing Euroregions. Surely, the purpose of their creation will be the implementation of specific public projects for borderland inhabitants, especially where it will be possible to raise additional EU funds. Previous achievements of Euroregions focus mostly on 'hard' infrastructure support projects. It seems important to create cross-border public communication systems and facilitate cooperation of local businesses. These options can be achieved thanks to a new legal instrument which is the EGTC. However, reliance on institutional system of „local government”, which is preferred by planned groupings, carries a risk of bureaucracy and monopolization of cooperation. So it seems necessary from the perspective of EGTCs to support the organizations operating on the borderland, as well as to give the most bottom-up character to the cooperation. Paths to come to this conjuncture may be to facilitate access of NGOs to EU funding through a pre-financing system, to simplify procedures for the beneficiaries or to de-politicize the process of allocation of EU funds. Formally, there has not yet been an EGTC established in Poland. Therefore, the assessment of the new EU legal instrument will only be possible from a long term perspective.

\section{BIBLIOGRAPHY}

Bussmann A., 2008. Europejskie ugrupowanie wspótpracy terytorialnej (EUWT) - przełom we wspótpracy transgranicznej w Unii Europejskiej?, „Samorząd Terytorialny”, 10, 8-11.

Dołzbłasz S., Raczyk A., 2010. Wspótpraca transgraniczna w Polsce po akcesji do UE, Oficyna Wolters Kluwer Business, Warszawa, 102, 200-204.

Dumała H., 2009a. Europejskie Ugrupowania Wspótpracy Terytorialnej - nowe możliwości dla polsko-niemieckich euroregionów, in: J. Jańczak, M. Musiał-Karg (eds.), Pogranicze polskoniemieckie po roku 2004. Nowa jakość sąsiedztwa, Wydawnictwo Adam Marszałek, Toruń, 63. 
Dumała H., 2009b. Współpraca międzyterytorialna w prawie Wspólnot Europejskich, „Annales UMCS", sectio K, 16, 41.

European Union Committee of the Regions webpage - http://portal.cor.europa.eu

„Gazeta Wyborcza” Daily webpage- http://wyborcza.pl

Konwencja o powotaniu Europejskiego Ugrupowania Wspótpracy Terytorialnej „Tatry” (draft), Materials of the Tatra Euroregion Office in Nowy Targ.

Konwencja o utworzeniu Europejskiego Ugrupowania Wspótpracy Terytorialnej „TRITIA” z ograniczonq odpowiedzialnościa, Materials of the Marshal Office of Silesian Voivodeship in Katowice.

Lewkowicz Ł., 2011. Euroregiony jako przykład wspótpracy transgranicznej na pograniczu Polski i Stowacji, Wydział Politologii, Lublin (unpublished doctoral dissertation), 132-152.

Od Euroregionu „,Tatry” do Europejskiego Ugrupowania Wspótpracy Terytorialnej, Materials of the Tatra Euroregion Office in Nowy Targ.

Opis działalności Stowarzyszenia Euroregion Karpacki Polska, Materials of the Carpathian Euroregion Office in Rzeszów.

Poland-Slovakia Programme 2007-2013 - http://pl.plsk.eu

Rozporzadzenie (WE) nr 1082/2006 Parlamentu Europejskiego i Rady z dnia 5 lipca 2006 roku w sprawie europejskiego ugrupowania wspótpracy terytorialnej (EUWT), Dz. Urz. UE nr L 210/19 z 31.07.2006.

Rozporzadzenie Ministra Spraw Zagranicznych z dnia 17 czerwca 2009 r. w sprawie sposobu prowadzenia Rejestru Europejskich Ugrupowań Wspótpracy Terytorialnej, Materials of the Ministry of Foreign Affairs in Warsaw.

Silesian Voivodeship Regional Bureau in Brussels webpage - http://www.silesia-europa.pl

SME Daily webpage - http://zilina.sme.sk

Sprawozdanie Rady Transgranicznego Zwiazku Euroregion Tatry z działalności w 2008 roku, Materials of the Tatra Euroregion Office in Nowy Targ.

Statut Europejskiego Ugrupowania Wspótpracy Terytorialnej „,TRITIA” z ograniczona odpowiedzialnościq, Materials of the Marshal Office of Silesian Voivodeship in Katowice.

Tatra EGTC webpage - http://www.euwt-tatry.eu

Tatra Euroregion webpage - http://www.euroregion-tatry.eu

Uchwała Nr 2 XVI Kongresu Transgranicznego Zwiazku Euroregion ,, Tatry” z dnia 24.03.2010 r. w sprawie: projektów strategicznych Transgranicznego Związu Euroregion „,Tatry”, Materials of the Tatra Euroregion Office in Nowy Targ.

Uchwała Nr 2 XVII Kongresu Zwiazku Euroregion „Tatry” z dnia 02.03.2011 r. w sprawie: Europejskiego Ugrupowania Wspótpracy Terytorialnej, Materials of the Tatra Euroregion Office in Nowy Targ.

Uchwała Nr 3 XV Kongresu Transgranicznego Związu Euroregion „Tatry” z dnia 17.04.2009 r. w sprawie: Deklaracji dotyczącej utworzenia Europejskiego Ugrupowania Wspótpracy Terytorialnej, Materials of the Tatra Euroregion Office in Nowy Targ.

Ustawa o Europejskim Ugrupowaniu Wspótpracy Terytorialnej, Dz. U. 2008, nr 218, poz. 1390.

Zákon o európskom zoskupeni územnej spolupráce a o doplneni zákona č. 540/2001 Z. z. o štátnej štatistike v zneni neskoršich predpisov - Zákon č. 90/2008 Zb. 
NOWE FORMY POLSKO-SŁOWACKIEJ WSPÓŁPRACY TRANSGRANICZNEJ

Streszczenie. Celem artykułu była analiza nowych form współpracy terytorialnej na pograniczu polsko-słowackim. Obecnie ten rodzaj współpracy realizują głównie euroregiony. Planowane przez Unię Europejską zmiany polityki spójności w latach 2014-2020 będą wpływały na przekształcenia strukturalno-funkcjonalne tych ,tradycyjnych” podmiotów. W artykule poddano analizie tworzące się obecnie na pograniczu europejskie ugrupowania współpracy terytorialnej „Tatry” i TRITIA oraz autorską koncepcję Euroregionu Karpackiego - „Karpacki Horyzont 2020”. Na wstępie wyjaśniona została istota i podstawy normatywne nowego instrumentu prawnego Unii Europejskiej, jakim jest europejskie ugrupowanie współpracy terytorialnej. Analizie poddano tworzone obecnie dwa polsko-słowackie ugrupowania oraz ideę „Karpackiego Horyzontu 2020”. Szczegółowo omówiono dokumenty założycielskie, organizację wewnętrzną i planowany zakres ich działalności.

Słowa kluczowe: europejskie ugrupowania współpracy terytorialnej, euroregiony, współpraca transgraniczna, pogranicze polsko-słowackie, „Karpacki Horyzont 2020” 